\title{
Soybean Crop: A Review on the Biotechnological Advances and Expectation for Modern Cultivars
}

\author{
Sebastião Soares de Oliveira Neto (Corresponding Author) \\ School of Agriculture, São Paulo State University (UNESP), Avenida Universitária, 3780, \\ Postal code 18610-034, Botucatu, São Paulo, Brazil \\ E-mail: neto.soliver@gmail.com \\ Jesion Geibel da Silva Nunes \\ School of Agriculture, São Paulo State University (UNESP), Avenida Universitária, 3780, \\ Postal code 18610-034, Botucatu, São Paulo, Brazil \\ E-mail: jesiongeibel@bol.com.br
}

Murilo de Souza

School of Agriculture, São Paulo State University (UNESP), Avenida Universitária, 3780, Postal code 18610-034, Botucatu, São Paulo, Brazil

E-mail: murilosouzaagro@hotmail.com

Juliano Carlos Calonego

School of Agriculture, São Paulo State University (UNESP), Avenida Universitária, 3780, Postal code 18610-034, Botucatu, São Paulo, Brazil

E-mail: julianocarloscalonego@gmail.com

Received: Oct. 23, 2019

doi:10.5296/jas.v8i1.15777
Accepted: Oct. 6, 2019

Published: Oct. 7, 2019

URL: https://doi.org/10.5296/jas.v8i1.15777

\begin{abstract}
The soybean crop is extremely important for Brazilian agribusiness, generating millions of dollars in the country's exports. Since its introduction in Brazil, soybean has undergone a process of technological modernization, receiving in the recent year's new technologies that
\end{abstract}


have provided a revolution in the production system, increasing mainly grain yield, as well as facilitated phytosanitary managements (pests, diseases, and weeds) and edaphoclimatic adaptation. Brazilian soybean producers yearn for new genotypes that make it easier to manage the crop and reduce input expenditures. New technologies are emerging or being improved to meet this demand. This review explores the technologies that are already available to soybean producers, inserted by the molecular breeding, such as Inox, Intacta, Cultivance, Libert Link and Enlist E3. It also brings the news that will be available to the market in a few years, such as Intacta 2 Xtend, $\mathrm{Hb} 4$, and other technologies to increase phenotyping and genotyping in breeding programs and insertion of characteristics to increase plant efficiency. Biotechnology is advancing at a frenetic pace and year after year, new techniques and tools are being made available for breeding programs around the world, which result in the production of new productive cultivars, conventional or transgenic, that are resistant to abiotic and biotic factors.

Keywords: Glycine max, plant breeding, biotechnology

\section{Introduction}

Soybean (Glycine max (L.) Merrill) is considered one of the oldest leguminous consumed by humankind. This crop occupies an important place on world food industry, offering oil for human consumption and a bran rich in proteins for animal feed. With the expectation of population growth and demand for plant protein, the use of soybeans increases each year (Contini et al., 2013; Gazzoni and Dall'agnol, 2018).

The role of technology is fundamental in the recent growth of Brazilian agriculture (Arias et al., 2018), a successful example is the developing of new soybean cultivars by Empresa Brasileira de Pesquisa Agropecuária. The cultivars started to be adapted to Brazil's edaphoclimatic conditions, spreading soybean production throughout the national territory and becoming a world reference in tropical crops.

In recent years, the increase in soybean yield has been provided by the adoption of biotechnology, which is an important tool to help plant breeding programs to obtain biotic and abiotic stress-resistant cultivars.

\section{Evolution, Chronology and Soybean's History}

First evidence of soybean cultivation date between 2.883 and 2.838 b.C. Until 1.894 a. C., the crop was restricted only to Chinese territory (Embrapa, 2019). On the second decade of XX century, some of the plant's characteristics, as the oil and protein content, awakened interest of food industries. However, tries of cultivation on Russia, England and Germany failed, probably because of their unfavorable weather conditions (Embrapa, 2019).

In the decade of 70 years, soybean was introduced in the South of Brazil, becoming a summer crop option. In that same period, Brazil started a great incentive for animal protein production such as swines and birds, contributing to a strong soybean bran demand (Fiesp, 2019).

The huge soybean cultivation appreciation with an explosion on its price on the global market caused the interest of the Brazilian government and farmers (Gazzoni and Dall'agnol, 2018; 
Contini et al., 2018). At this time, the country started to invest in innovations and technologies focused on farming adaptations to Brazil's climate conditions, especially in the Cerrado region, extending soybean territorial growth, process led by Embrapa.

The soybean planting was restricted only to areas whose latitude was near $30^{\circ} \mathrm{N} / \mathrm{S}$ or bigger than that. With the soybean breeding, this barrier was deleted, and the species was suited to tropical conditions were developed, allowing, this way, the cultivation expansion to Mercosur and all over the Brazilian territory (Gazzoni and Dall'agnol, 2018; Embrapa, 2019).

Brazil cultivated about 35.7 million hectares in the 2018/2019 season and produces approximately 18.8 million tonnes of soybean (Conab, 2019). Soybean grain yield increased from 1,748 mil kg.ha ${ }^{-1}$ in $1976 / 77$, to $3,322 \mathrm{~kg} \cdot \mathrm{ha}^{-1}$ in $2018 / 19$. Its production increased above $370 \%$ in the last 40 years whereas its grain yield increased $64.2 \%$ in the same period.

The main reasons that provided a great jump in soybean production in the last decades were: cultivars adapted to tropical climate and low latitudes; correction of Cerrado soils; adaptation of agricultural machinery; seed quality and phytosanitary management (Kiihl et al., 1985; Almeida et al., 1999; Mundstock and Thomas, 2005; França-Neto et al., 2016; Embrapa Soja, 2013; Juhász et al., 2013).

According to 2017-2026 Agricultural Outlook (Oecd/Fao, 2017), soybean must continue being Brazilian's main agricultural product in the next years, because the price will remain relatively high and the protein demand continues.

Today, many different farmers explore soybean crop: the big ones that faces the exploration as a real business company and the small ones that see in soybean on option to increase their incomes (Garret et al., 2013).

Regardless of the amount of cultivated area, all national soybean producers share the same technology that is offered from cultivars available in the market and all of them have in mind what modern cultivars should have.

\section{Available Technologies in Soybean Crop}

The recent biotech revolution is affecting the power and efficiency of the breeding process. There is an increase in the capacity of researchers to analyze large populations of plants and we are on the brink of being able to fully sequence the genome of a large number of plants (Thomson, 2014).

According to Carrer et al. (2010) and Usda (2017), genetic manipulation of plants using engineering techniques permits the expression of interest genes, resulting in solutions to problems that affect agriculture.

Biotechnology is a tool to assist in the reduction of pesticide use and to increase food offer. The main benefit for the farmers is the costs decrease, the pests and weed management facilities and the increase in the grain yield (Embrapa Soja, 2013; Bawa, 2013; Burketova et $a l ., 2015)$. For these reasons, in the last Brazilian crop, use of $96.5 \%$ of transgenic soybean was observed. 


\section{Mll Macrothink}

Journal of Agricultural Studies

ISSN 2166-0379

2020, Vol. 8, No. 1

According to Ainsworth et al. (2012), the soybean breeders must adopt biotechnological advances that facilitate the incorporation of yield enhancement genes.

Every year new technologies are released and under the analysis and approval of genetically modified organism's regulatory committee, they can be used or not. Next, we present the technologies that have been used by the soybean production chain Brazil.

\subsection{Roundup Ready ${ }^{\circledR}$}

The first transgenic event in the soybean crop was glyphosate resistant, technology called Roundup Ready ${ }^{\circledR}$ - RR, developed by Monsanto Company in 1995 and released for commercialization in Brazil in 1998 (Cib, 2019).

The tolerance gene gives plants tolerance to the post-emergence application of glyphosate molecule. This gene was isolated from a bacterium called Agrobacterium spp found in an effluent tank at a glyphosate production factory. The gene was introduced into soybean plants through the biobalistic process, where DNA segments of this bacterium were introduced into plant cells (Pioneer, 2019).

According to Padgette et al. (1995), RR soybeans showed resistance to the herbicide glyphosate, due to the expression of the enzyme 5-enolpyruvylchiquimate-3-phosphate synthase (EPSPS), extracted from the Agrobacterium spp.

The glyphosate molecule acts on the plant by blocking the enzyme EPSPS, which is part of the biosynthetic pathway of aromatic amino acids essential for plant development. When this enzyme is blocked, the metabolic pathway is disrupted and due to lack of amino acids, the plant dies. In transgenic plants, the metabolic pathway is not interrupted and the plants develop normally (Pioneer, 2019; Zablotowicz and Reddy, 2007).

$3.2 B t^{\circledR}$

Since the 90's, options to soybean pests control has been searched, especially for caterpillars such as Anticarsia gemmatalis Hübner (Lepidoptera: Erebidae), Chrysodeixis includens Walker (Lepidoptera: Noctuidae) and Helicoverpa armigera (Lepidoptera: Noctuidae: Heliothinae) (Figure 1, a, b e c).

(a)

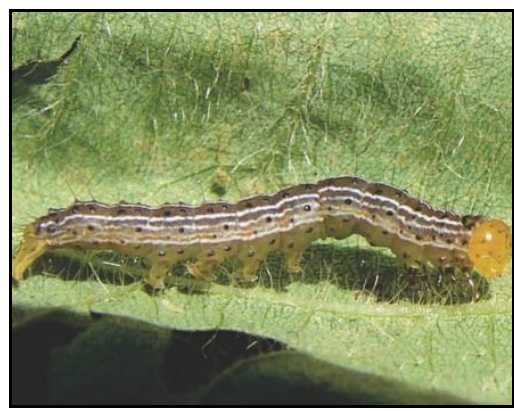

(b)

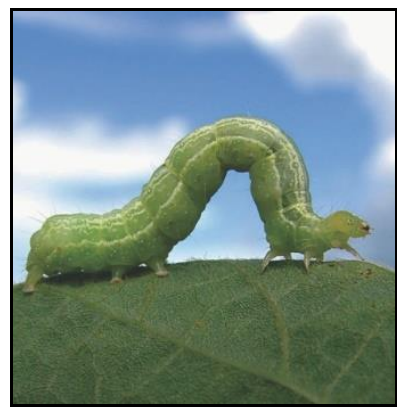

(c)

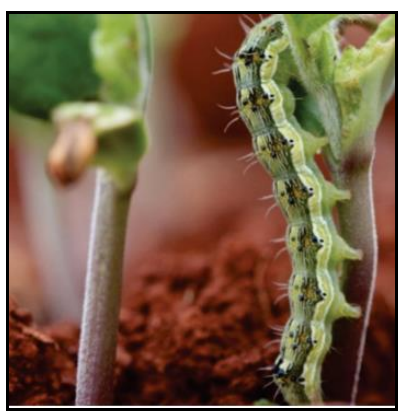

Figure 1. Soybean crop pests: Anticarsia gemmatalis (a), Chrysodeixis includens (b) and Helicoverpa armigera (c)

Source: Crébio José Ávila (a and b); André Katsuo Shimohiro (c) 
Nowadays, biotechnology is the most important tools to manage soybean phytosanitary aspects. For example, in order to control insects, there is the Bacillus thuringiensis technology $(\mathrm{Bt})$. Plants with this innovation express genes that codify Cry protein and it represents a new alternative to control the main complex of caterpillars in soybean crop (Calvo and Garcia, 2014). In Bt soybean plants, Cry1Ac protein has insecticide activity when ingested by caterpillars. The protein is activated by the alkaline $\mathrm{pH}$ of the gut of insects, destroying the gut wall cells and causing the death of caterpillars.

Bt technology advantage is pest control during all the harvest cycle, especially in the critic stages, performing an efficient control and avoiding pests reinfestation. Besides, it reduces the number of insecticide pulverization and the risk of environmental contamination.

\section{$3.3 \operatorname{Inox}^{\circledR}$}

Asian rust has been described for the first time in South America's 2000/2001 season, when it was found in Brazil, Paraguay and, Argentina. Caused by Phakopsora pachyrhizi fungus, have shown highly aggressive, becoming one of the main soybean pest (Sinclair and Hartman, 1999). Figure 2 (a) illustrates Asian rust in soybean leaf.

(a)

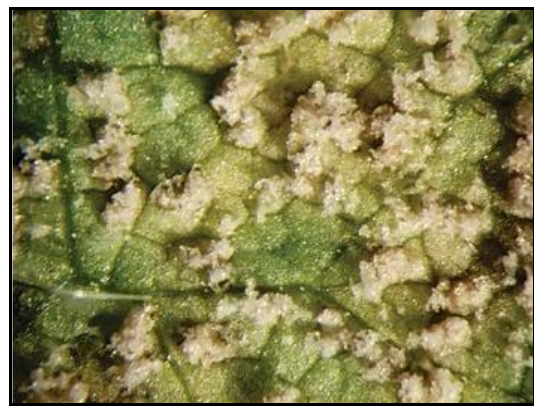

(b)

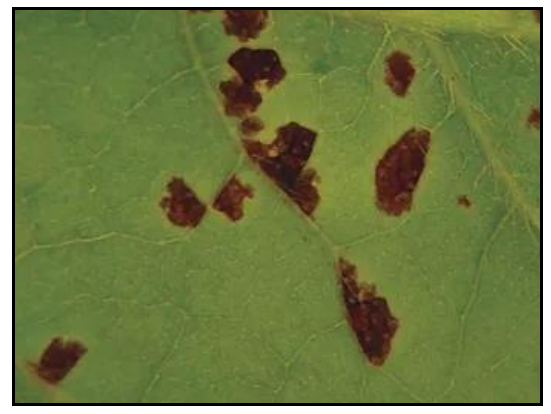

Figure 2. Soybean leaf susceptible to rust (a) and soybean leaf resistant to rust (b)

Source: Tropical Melhoramento \& Genética

Although it demands a huge effort looking for new fungus resistance source, this acquisition is hampered by the large variability of this microorganism. P. pachyrhizi fungus express and/or develop new pathogenic breeds that can break the resistance of new cultivars.

Searching for resistant genotypes, the United States formalized a trademark for the Rpp5 gene selection, which promotes resistance to Asian rust (King et al., 2016). The method facilitates the development of resistant varieties to this pest.

The trademark, which isolates the Rpp5 gene, was given to Tropical Melhoramento \& Genética - TMG. This method uses the genetic roadmap, by the assisted selection done by molecular markers, in order to discover the plant DNA sequence that is related to the resistance gene (Tmg, 2017). Inox ${ }^{\circledR}$ technology has the capability to resist the fungus attack and to decrease pest progress. Moreover, the resistance gene allows the plant to have higher conditions to live with the pest on the field. When the fungus attack the leaves of soybean resistant (Figure 2 - b), the plant reacts producing a brown-reddish injury, which avoids the sporulation and the installation of illness. 
This technology can postpone the beginning of fungicide application, reduces the illness progress in the plantations, maintain the cultivars' yield potential and contributes to the reduction of fungicides use (Tmg, 2017).

\subsection{Intacta $^{\circledR}$ and Intacta RR2 Pro ${ }^{\circledR}$}

Monsanto developed the $\operatorname{Intacta}^{\circledR}$, which permits resistance to many types of caterpillars that are soybean crop pests (Jhala et al., 2017).

According to Bernardi et al. (2012), this technology confers tolerance to glyphosate and exhibits control against major caterpillars: Anticarsia gemmatalis, Chrysodeixis includes, Heliothis virescens, Crocidosema aporema, Elasmopalpus lignosellus, Helicoverpa zea and Helicoverpa armigera.

The Intacta RR2 Pro ${ }^{\circledR}$ was released in 2012 and combines resistance to glyphosate and other species of caterpillars. It is the first soybean biotechnology specially developed for the Brazilian market, which before being commercially launched in Brazil was approved in the main soybean consuming countries of the world, to guarantee, besides the best production, the exportation of harvested soybeans (Monsanto, 2016).

\subsection{Cultivance ${ }^{\circledR}$}

Cultivance $^{\circledR}$ is a technology developed together with public and private corporate sectors, brought to the farmers the possibility to use one more herbicide active to control weeds. In this technology, csr1-2 gene, obtained from Arabidopsis thaliana, vests resistance to imidazolinone herbicides, which inhibition of acetolactate synthase ALS (acetohydroxyacid synthase) (Oliveira Junior, 2011; Calvo and Garcia, 2014). Imidazolinone is efficient to control weeds that have acquired resistance because of the continuous use of glyphosate, as in the case of Digitaria insularis and Conyza bonariensis species.

This way, Cultivance ${ }^{\circledR}$ technology can offer to soybean farmers the possibility of rotate herbicides with different modes of action, mitigating problems related to resistance (Wright $e t$ $a l ., 2010)$. On the other hand, it can also contribute to the decrease of selection pressure in weeds plants that do not present resistance.

Another Cultivance ${ }^{\circledR}$ technology characteristic in soybean cultivars is the possibility of doing the management of weeds before the sowing or in the pre-sowing period, guaranteeing an efficient control until the end of the crop, discharging the post-emergence herbicide applications (Calvo and Garcia, 2014).

\subsection{Liberty Link ${ }^{\circledR}$}

Liberty Link ${ }^{\circledR}$ is a biotechnological progress to soybean crop that can help farmers in the control of weeds that are resistant to other herbicides types. Bayer Company created this technology by inserting the pat gene found in the Streptomyces viridochromogenes bacteria (Calvo and Garcia, 2014). This gene, when placed inside the plant, catalyzes the Lphosphinothricin and ammonium glufosinate to non-toxic products, providing resistance to the active ingredients (Ctnbio, 2015). 


\section{Macrothink}

Journal of Agricultural Studies

ISSN 2166-0379

2020, Vol. 8, No. 1

Ammonium glufosinate is used to control weeds, being one more strategic option to the soybean crop management.

\subsection{Conkesta Enlist E3 ${ }^{\circledR}$}

Conkesta Enlist E3 ${ }^{\circledR}$ technology was created by Dow AgroScience Company and approved in 2017 by Ctnbio, to weeds control in soybean crop.

Unlike other related technologies, such as Roundup Ready ${ }^{\circledR}$, Cultivance ${ }^{\circledR}$ and Liberty Link ${ }^{\circledR}$, which each one confers resistance to a specific isolated herbicide, this technology offer resistance to three distinct active ingredients: glyphosate, ammonium glufosinate and 2, 4-D and which has two genes (cry1Ac e cry1F) resistant to insects (Calvo and Garcia, 2014; Dow Agrosciences, 2017).

The glufosinate resistance is given by 2 mepsps gene (Isaa, 2017) that is better improved than EPSPS from corn, which was changed through a site directed-mutation in two amino acid sequence of the original peptide sequence (Calvo and Garcia, 2014; Ctnbio, 2015).

The ammonium glufosinate resistance is similar to Liberty Link ${ }^{\circledR}$ technology whereas 2, 4-D resistance is given by aad-12 gene, extracted from Delftia acidovorans bacteria (Wright et al., 2010; Isaa, 2017).

A soybean genotype that combines resistance to three different types of active ingredients present in herbicides can be an option to have an efficient weed management. With this technology, it is possible to use different herbicide in distinct applications or even to make blends, controlling tolerant plants and avoiding the appearance of new resistant biotype.

\subsection{Soybean Genotypes with Conventional Technology}

However, natural resistance can be explored to develop conventional soybean, over the years, some pest's resistant soybean genotypes have been selected.

Still in 2010/2011 season, Embrapa in partnership with Secretaria da Agricultura of Goiás State - Brazil, launched a soybean cultivar partly resistant to Asian rust. The BRSGO 7560 variety has this partial resistance and, because of that, reduces in $2 / 3$ fungicides application. Figure 3 shows the BRSGO 7560 variety (on the right) owned beside of a susceptible to Asian rust variety.

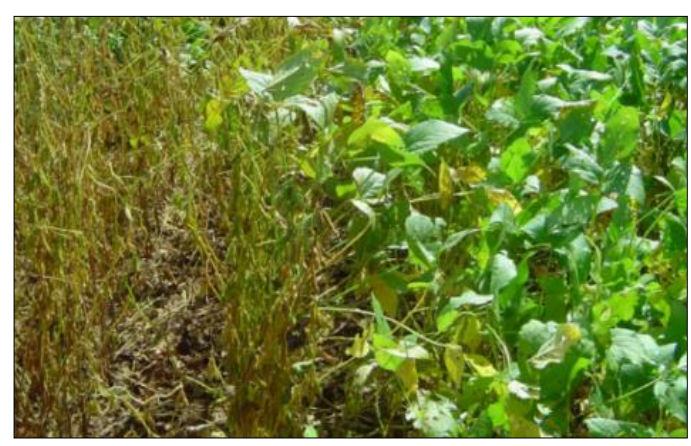

Figure 3. Susceptible and resistant soybean cultivars, cultivated side by side

Source: Jornal Dia de Campo. 
A huge problem of the soybean crop is the damage caused by many species of bugs. Using resistant genotypes can be an alternative to control losses caused by these bugs and to achieve higher levels of grain yield. Resistant cultivars are less attractive for bugs, resulting in lower losses of production and better seed quality (Contini et al, 2018).

Embrapa created the BRS 391 cultivar, which is tolerant to soybean bed bugs, requiring fewer insecticides (Corrêa-Ferreira et al., 2016).

Several Brazilian public universities (Esalq - USP, UEM, UEL, UFV, and others) also have breeding programs to develop conventional insect resistant soybean cultivars.

\section{Technologies in Trial Phase}

The achieving a quantum leap in soybean yields and yield potential will almost certainly require biotechnological advances that enable improvement of multiple traits (Ainsworth et $a l ., 2012)$. The use of new biotechnological tools in soybean breeding to decrease climatic and environmental factors impacts is receiving a lot of attention (Chen et al., 2014). Recent molecular biology progress eases the identification of molecular markers and functional genes related to drought tolerance in soybean (He et al., 2017).

The input of genes with the abscisic acid (ABA) transcription factors is largely studied, with promising results for standard plants and for economic importance cropping (Yoshida et al., 2010). These genes allow the plant to receive and to identify environmental signals of abiotic stress, activating and regulating the genetic expression (Barbosa et al., 2012). Promising results are found in Arabidopsis (Fujita et al., 2005) and soybean (Marinho et al., 2016).

\subsection{Embrapa Technology for Drought Tolerance}

Fuganti-Pagliarini et al. (2017) studying the BR 16 cultivar (considered vulnerable to drought) and three transgenic isoline, verified that one isoline produced a higher number of pods, seeds and seed dry matter. The isoline best performance, comparing to BR16 plants, is related to the decrease of stomatal conductance and transpiration. Those results suggest that the transgenic genotype improved capability to handle drought, without loss of yield (Figure 4) (Marinho et al., 2016). 


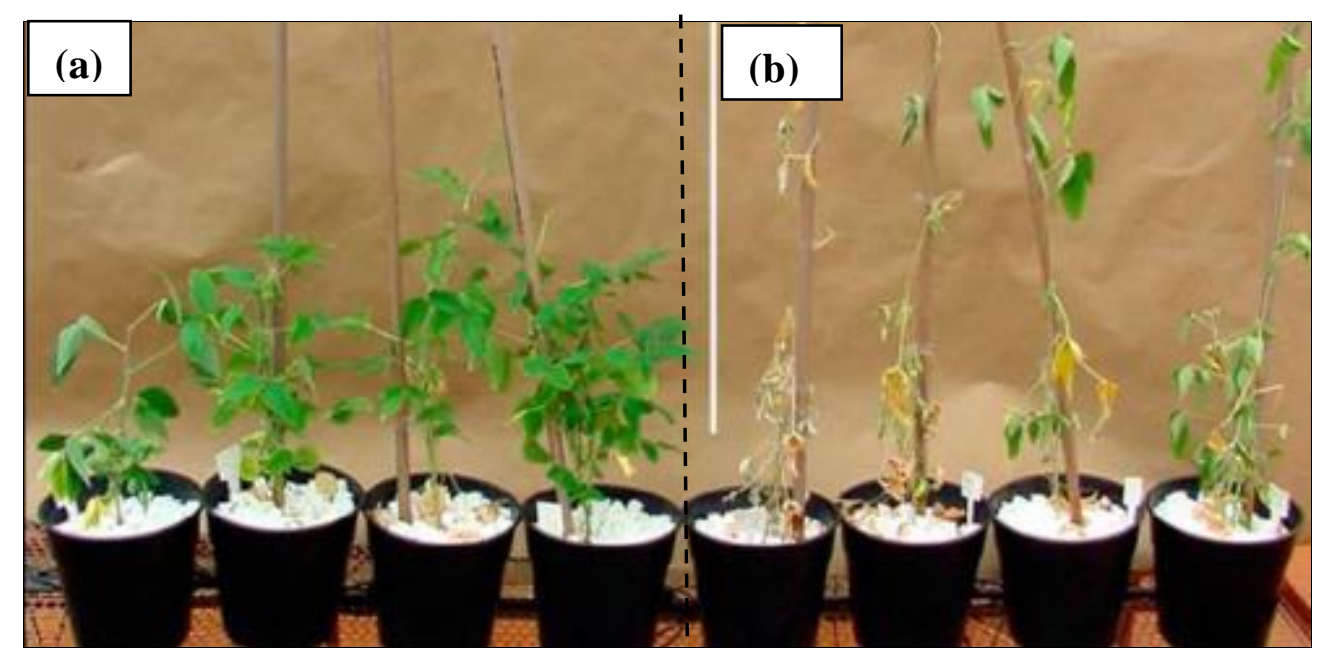

Figure 4. Soybean genotype with drought resistance gene (a) and without resistance gene (b)

Source: Adapted from Lebna Landgraf/Embrapa Soja; Alexandre Nepumoceno

In the coming years, Embrapa will make available to the soybean market, new cultivars with drought tolerance technology already inserted in the materials.

\section{$4.2 H B 4^{\circledR}$}

Begun in 2015, the partnership between the national company Tropical Melhoramento e Genética S/A - TMG with Verdeca LLC, a joint venture of the companies Bioceres S/A and Arcadia Biosciences, provided the development of $\mathrm{Hb} 4{ }^{\circledR}$ soybeans, with a trait that confers on soybeans the tolerance to drought stress. The plants have superior response under conditions of water stress with up to $30 \%$ increase in grain yield in drought situations (Tmg, 2019).

\section{$4.3 \operatorname{Hppd}^{\circledR}$}

The $\mathrm{Hppd}^{\circledR}$ technology was created by Bayer S.A. and offers resistance to isoxaflutole herbicide through hppdPfw336 gene found in Pseudomonas fluorescens bacteria. The isoxaflutole active ingredient acts inhibiting Hppd enzyme that in the plant is engaged to tyrosine catabolism, taking part in the photosynthetic process. With the modification in Hppd enzyme, encoded by the hppdPfw336 mutant gene, the affinity to isoxaflutole herbicide decreases, conferring resistance (Ctnbio, 2015).

The event was authorized by Ctnbio in 2011 and is in the testing phase. There is no forecast for the release of the technology.

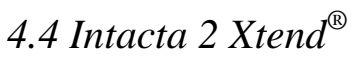

In the next years, it will happen the commercial launch of Intacta 2 Xtend $^{\circledR}$ (foreseen to 2021, depending on international certifications). This new technology will arrive in the agricultural market to provide weeds and insect management, impacting positively the grain yield. In this new technology, it was added in soybean two new proteins that will provide a strong management against aim caterpillars in Intacta RR2 Pro ${ }^{\circledR}$ soybean (Dino, 2018). 
Materials that have this technology, express dmo (dicamba monooxygenase) gene, extracted from Stenotrophomonas maltophilia bacteria, making them resistant to dicamba herbicide (Ctnbio, 2015). This herbicide is used on a large scale to control dicotyledonous weed plants (large leaves) (Calvo and Garcia, 2014).

The soybean is tolerant to dicamba and glyphosate herbicides and will allow a new grain yield standard to Brazilian farmers. The forecast is that pre-commercial tests in producer's fields will start in 2019/2020 season (Dino, 2018).

\section{Advances in Soybean Breeding}

Other biotechnological advances aid in soybean breeding such as the capacity to analyze DNA exponentially, developments in the phenotyping technology and the soybean plant physiological modifications promoted by biotechnological tools.

Advances in phenotyping technology are critical to ensure the genetic improvement of crops meet future global demands for food and fuel. Yu et al. (2016) developed an UAV method-based HTP platform, to improve soybean yield estimation and predict plant maturity with an unmanned aerial vehicle based platform. This new technology will reduce the current imbalance between phenotyping and genotyping and increase the efficiency of phenotypic data collection in large-scale breeding programs.

Several biotechnological alternatives may be inserted and used in soybean crop in the coming years, including improved photosynthetic and respiratory efficiency, increased allocation of $\mathrm{C}$ and $\mathrm{N}$ to developing pods, synchronized floral initiation to promote greater pod survival and optimized soybean- Rhizobia compatibility (Ainsworth et al., 2012).

\section{Conclusion}

The advancement of biotechnology in agriculture has revolutionized soy production in Brazil and worldwide. With the advent of transgenic, technologies were implemented using genetically modified organisms that allowed the management of pests, diseases, and weeds by inserting resistance genes extracted from exogenous species.

Biotechnology is advancing at a frenetic pace and year after year, new techniques and tools are being made available for breeding programs around the world, which result in the production of new productive cultivars, conventional or transgenic, that are resistant to abiotic and biotic factors.

\section{References}

Ainsworth, E. A., Yendrek, C. R., Skoneczka, J. A., \& Long, S. P. (2012). Accelerating yield potential in soybean: potential targets for biotechnological improvement. Plant Cell and Environment, 35(1), 38-52. https://doi.org/10.1111/j.1365-3040.2011.02378.x

Almeida, L. A., Kiihl, R. A. S., Miranda, M. A. C., \& Campelo, G. J. A. (1999). Melhoramento da soja para regiões de baixas latitudes, In: (M. A. Queiroz, C. O Goedert, \& S. R. R. Ramos (Eds.), Recursos genéticos e melhoramento de plantas para o Nordeste brasileiro. Petrolina: Embrapa Semi-Árido. 
Arias, D., Vieira, P. A., Contini, E., Noronha Farinelli, B. C., \& Morris, M. (2018). Agricultural Productivity Growth in Brazil - recent trends and future prospect. Washington: World Bank Group. p. 61.

Barbosa, E. G. G., Leite, J. P., Marin, S. R. R., Marinho, J. P., Corrêa, C. J. F., Fuganti-Pagliarini, R., ... Nepomuceno, A. L. (2012). Overexpression of the ABA-dependent AREB1 transcription factor from Arabidopsis thaliana improves soybean tolerance to water deficit. Plant Molecular Biology Reporter, 31(3), 719-730.

https://doi.org/10.1007/s11105-012-0541-4

Bawa, A. (2013). Safety, risks, and common concerns: Genetically Modified Foods. Journal of Food Science and Technology, 50(6), 1035-1046.

Bernardi, O., Malvestiti, G. S., Dourado, P. M., Oliveira, W. S., Martinelli, S., Berger, G. U., ... Omoto, C. (2012). Assessment of the high -dose concept and level of control provided by MON 87701 x MON 89788 soybean against Anticarsia gemmatalis and Pseudoplusia includens (Lepidoptera: Noctuidae) in Brazil. Pest Management Science, 68(7), 1083-1091. https://doi.org/10.1002/ps.3271

Burketova, L., Trda, L., Ott, P. G., \& Valentova, O. (2015). Bio-based resistance inducers for sustainable plant protection against pathogens. Biotechnology Advances, 33(6), 994-1004. https://doi.org/10.1016/j.biotechadv.2015.01.004

Calvo, E., \& Garcia, A. (2014). Biotecnologia na soja: os transgênicos nos próximos cinco anos. In: A. Galhardi Junior, F. Siqueri, J. Caju \& S. Camacho (Eds.). Boletim de pesquisa de soja 2013/14. Rondonópolis: Fundação de Apoio à Pesquisa Agropecuária de Mato Grosso.

Carrer, H., Barbosa, A. L., \& Ramiro, D. A. (2010). Biotechnology in agriculture. Estudos Avançados, 24(70), 149-164.

Chen, M. X., Lung, S. C., Du, Z. Y., \& Chye, M. L. (2014). Engineering plants to tolerate abiotic stresses. Biocatalysis and Agricultural Biotechnology, 3(1), 81-87.

https://doi.org/10.1016/j.bcab.2013.09.010

Cib (2019). Conselho de informações sobre biotecnologia. Aprovação de culturas GM no Brasil. Retrived from https://cib.org.br/aprovacao-de-culturas-gm-no-brasil/

Conab (2019). Acompanhamento da Safra Brasileira de Grãos, Safra 2018/2019. Primeiro Levantamento. Brasília: Conab. p. 46.

Contini, E., Gazzoni, D., Aragão, A., Mota, M. \& Marra, R. (2018). Série desafios do agronegócio brasileiro - Complexo soja - Caracterização e Desafios Tecnológicos. Embrapa. Retrived from

https://www.embrapa.br/documents/10180/0/COMPLEXO+SOJA+-+Caracteriza\%C3\%A7\% C3\%A3o+e+Desafios+Tecnol\%C3\%B3gicos/709e1453-e409-4ef7-374c-4743ab3bdcd6

Contini, E., Pena Jr, M., \& Vieira, P. A. (2013). Drought in the USA: agricultural prices and implications for Brazil. Revista de Política Agrícola, 22(1), 85-97. 


\section{$\triangle$ Macrothink}

Journal of Agricultural Studies

ISSN 2166-0379

2020, Vol. 8, No. 1

Corrêa-Ferreira, B. S., Hoffmann-Campo, C. B., Lima, D., \& Arias, C. A. A. (2016). Tolerância da soja BRS 391 aos danos de percevejos sugadores de grãos. In: Reunião de pesquisa de soja. Londrina: Embrapa Soja.

Ctnbio (2015). Parecer Técnico $\mathrm{N}^{\mathrm{o}}$ 4866/2015. Retrived from http://ctnbio.mcti.gov.br/documents/566529/1702549/Parecer+T\%C3\%A9cnico+n\%C2\%BA $\% 204866+-+2015 / 2$ b54da35-d7c1-43ff-91b4-62d9491e3e27;jsessionid=0447CC174D41F23 70FC3AF3C7DC7ED47.rima?version=1.0

Dino (2019). Intacta 2 Xtend® promoverá debate sobre manejo de resistência durante o Congresso Brasileiro da Ciência das Plantas Daninhas. Retrived from

https://exame.abril.com.br/negocios/dino/intacta-2-xtend-promovera-debate-sobre-manejo-de -resistencia-durante-o-congresso-brasileiro-da-ciencia-das-plantas-daninhas/

Dow Agrosciences (2017). Sala de Imprensa. Retrived from http://www.dowagro.com/pt-br/brasil/press/press-release/2017/03/tecnoshow

Embrapa (2019). Embrapa Soja. Retrived from: https://www.embrapa.br/soja

Embrapa Soja (2013). Tecnologias de produção de soja - região Central do Brasil 2014. Londrina: Embrapa Soja. p. 265.

Fiesp (2019). Soja e suas riquezas-História. Retrived from http://www.fiesp.com.br/sindimilho/sobre-o-sindmilho/curiosidades/soja-e-suas-riquezas-hist oria

França-Neto, J. B., Krzyzaniwski, F. C., Henning, A. A., Pádua, G. P., Lorini, I., \& Henning, F. A. (2016). Tecnologia de produção de semente de soja de alta qualidade. Londrina: Embrapa Soja. p. 82.

Fuganti-Pagliarini, R., Ferreira, L. C., Rodrigues, F. A., Molinari, H. B. C., Marin, S. R. R., Molinari, M. D. C., ... Nepomuceno, A. L. (2017). Characterization of soybean genetically modified for drought tolerance in field conditions. Frontiers in Plant Science, 8, 1-15. https://doi.org/10.3389/fpls.2017.00448

Fujita, Y., Fujita, M., Satoh, R., Maruyama, K., Parvez, M. M., Seki, M., ... Yamaguchi-Shinozakia, K. (2005). AREB1 is a transcription activator of novel ABRE dependent ABA signaling that enhances drought stress tolerance in Arabidopsis. Plant Cell, 17(1), 3470-3488. https://doi.org/10.1105/tpc.105.035659

Garret, R. D., Lambin, E. F., \& Naylor, R. L. (2013). Land institutions and supply chain configurations as determinants of soybean planted area and yield in Brazil. Land Use Policy, 31, 385-396. http://dx.doi.org/10.1016/j.landusepol.2012.08.002

Gazzoni, D. L., \& Dall'agnol, A. (2018). A saga da soja - de 1050 a.C a 2050 d. C. Brasília: Embrapa. p. 199.

He, J., Du, Y. L., Wang, T., Turner, N. C., Yang, R. P., Jin, Y., .. Li, F. M. (2017). Conserved water use improves the yield performance of soybean (Glycine max (L.) Merr.) under drought. 
Agricultural Water Management, 179(1), 236-245.

https://doi.org/10.1016/j.agwat.2016.07.008

Isaa (2017). GM Approval Database. Retrived from http://www.isaaa.org/gmapprovaldatabase/gene/default.asp?GeneID=22

Jhala, A. J., Sandell, L. D., Sarangi, D., Kruger, G. R., \& Knezevic, S. Z. (2017). Control of glyphosate-resistant common waterhem (Amaranthus rudis) in glufosinate-resistant soybean. Weed Technology, 31(1), 32-45. https://doi.org/10.1017/wet.2016.8

Juhász, A. C. P., Pádua, G. P., Wruck, D. S. M., Favoreto, L., \& Ribeiro, N. R. (2013). Desafios fitossanitários para a produção de soja. Informe Agropecuário, 34(276), 66-75.

Kiihl, R. A. S., Almeida, L. A., \& Dall'agnol, A. (1985). Strategies for cultivar development in the tropics. In: World Soybean Research Conference III. Proceedings, Ames.

King, Z. R., Harris, D. K., Pedley, K. F., Song, Q., Wang, D., Wen, Z., ... Boerma, H. R. (2016). A novel Phakopsora pachyrhizi resistance allele (Rpp) contributed by PI 567068A. Theoretical and Applied Genetics, 129(3), 517-534.

https://doi.org/10.1007/s00122-015-2645-3

Marinho, J. P., Kanamori, N., Ferreira, L. C., Fuganti-Pagliarini, R., Corrêa Carvalho, J. F., Freitas, R. A., ... Nepomuceno, A. L. (2016). Characterization of molecular and physiological responses under water deficit of genetically modified soybean plants overexpressing the AtAREB1 transcription factor. Plant Molecular Biology Reporter, 34(2), 410-426. https://doi.org/10.1007/s11105-015-0928-0

Monsanto (2016). Intacta RR2 PRO. Retrived from http://www.intactarr2pro.com.br/a-intacta

Mundstock, C. M., \& Thomas, A. L. (2005). Soja: fatores que afetam o crescimento e o rendimento de grãos. Porto Alegre: Evangraf. p. 31.

Oecd/Fao (2017). Agricultural Outlook 2017-2026, OECD Publishing, Paris. Retrived from http://dx.doi.org/10.1787/agr_outlook-2017-en

Oliveira Junior, R. S. (2011). Mecanismo de ação dos herbicidas. In: R. S. Oliveira Junior, J. Constantin, M. H. Inouse (Eds.). Biologia e Manejo de Plantas Daninhas. (pp. 1-36). Curitiba: Omnipax.

Padgette, S. R., Kolacz, K. H., Delannay, X., Re, D. B., LaVallee, B. J., Tinius, C. N., ... Kishore, G. M. (1995). Development, identification, and characterization of a glyphosate-tolerant soybean line. Crop Science, 5(35), 1451-1461.

https://doi.org/10.2135/cropsci1995.0011183X003500050032x

Pioneer (2019). Tolerante ao glifosato. Retrived from

http://www.pioneersementes.com.br/biotecnologia/tolerante-ao-glifosato

Sinclair, J. B., \& Hartman, G. L. (1999). Soybean rust. In: G. L. Hartman, J. B. Sinclair, J. C. Rupe (Eds.). Compendium of soybean diseases. (pp.25-26). St. Paul: American Phytopathological Society. 


\section{Macrothink}

Thomson, M. J. (2014). High-throughput SNP genotyping to accelerate crop improvement. Plant Breeding Biotechnology, 2(3), 195-212. http://dx.doi.org/10.9787/PBB.2014.2.3.195

Tmg (2017). Tropical Melhoramento e Genética. Tecnologia Inox ${ }^{\circledR}$. Retrived from http://www.tmg.agr.br/tecnologia-inox

Tmg (2019), Tropical Melhoramento e Genética. Soja tolerante à seca será alternativa para estiagens como a dessa safra. Retrived from

http://www.tmg.agr.br/pt/noticia/soja-tolerante-a-seca-sera-alternativa-para-estiagens-como-a -dessa-safra

Usda (2017). United States Departament of Agriculture. National Agriculture Statistic Service - Corn and Soybean Production Up in 2016, USDA Reports Winter Wheat Seedings and Grain Stocks also reported. Retrived from

https://www.nass.usda.gov/Newsroom/2017/01_12_2017.php

Wright, T. R., Shan, G., Walsh, T. A., Lira, J. M., Cui, C., Song, P., ... Zhang, Z. (2010). Robust crop resistance to broadleaf and grass herbicides provided by aryloxyalkanoate dioxygenase transgenes. Proceedings of the National Academy of Sciences, 107(47), 20240-20245. https://doi.org/10.1073/pnas.1013154107

Yoshida, T., Fujita, Y., Sayama, H., Kidokoro, S., Maruyama, K., Mizoi, J., ... Yamaguchi-Shinozaki, K. (2010). AREB1, AREB2, and ABF3 are master transcription factors that cooperatively regulate ABRE-dependent ABA signaling involved in drought stress tolerance and require ABA for full activation. The Plant Journal, 61(4), 672-685. https://doi.org/10.1111/j.1365-313X.2009.04092.x

Yu, N., Li, L., Schmitz, N., Tian, L. F., Greenberg, J. A., \& Diers, B. W. (2016). Development of methods to improve soybean yield estimation and predict plant maturity with an unmanned aerial vehicle based platform. Remote Sensing Environment, 187(1), 91-101. https://doi.org/10.1016/j.rse.2016.10.005

Zablotowicz, R. M., \& Reddy, K. N. (2007). Nitrogenase activity, nitrogen content, and yield responses to glyphosate in glyphosate-resistant soybean. Crop Protection, 26(3), 370-376. https://doi.org/10.1016/j.cropro.2005.05.013

\section{Copyright Disclaimer}

Copyright for this article is retained by the author(s), with first publication rights granted to the journal.

This is an open-access article distributed under the terms and conditions of the Creative Commons Attribution license (http://creativecommons.org/licenses/by/4.0/). 